\title{
Biliary excretion of biochemically active cyanobacteria (blue-green algae) hepatotoxins in fish
}

\author{
A. Sahin ${ }^{a}$, F.G. Tencalla ${ }^{b}$, D.R. Dietrich ${ }^{\text {b,c }}$, H. Naegeli*a \\ ${ }^{a}$ Institute of Pharmacology and Toxicology, University of Zürich-Tierspital, Winterthurerstr. 260, 8057 Zürich, Switzerland \\ ${ }^{\mathrm{b}}$ Institute of Toxicology, Federal Institute of Technology and University of Zurich. Schorenstr, 16. \\ 8603 Schwerzenbach, Switzerland \\ 'University of Pirtsburgh, Department of Environmental and Occupational Health, RIDC Park, 260 Kappa Drive, \\ Pittsburg, PA 15238. USA
}

\begin{abstract}
Previous reports demonstrated that microcystin and related cyanobacteria polypeptides are rapidly cleared from plasma and accumulate in liver tissue. In the present study, we have used their ability to inhibit protein phosphatases to show that these cyanobacteria hepatotoxins are excreted into the bile of experimentally poisoned rainbow trout. At various times after oral administration of hepatotoxic Microcystis aeruginosa, bile samples were analysed for microcystin content by methanol extraction and protein phosphatase assays. An inhibitory principle that specifically suppressed protein phosphatase activity was detected in all bile samples removed between 1 and $72 \mathrm{~h}$ after oral exposure to toxic algae. These results indicate that biochemically active microcystin molecules are excreted into the biliary tract of poisoned fish.
\end{abstract}

Keywords: Microcystin; Hepatotoxicity; Phosphatase; Organic ion transporter

\section{Introduction}

Microcystins are a family of cyclic polypeptides produced by several species of freshwater cyanobacteria (Carmichael et al., 1988). These microorganisms have been reported to cause poisonings of wild and domestic animals in many parts of the

Abbreviations: Adda, 3-amino-9-methoxy-2,6,8-trimethyl10-phenyldeca-4,6-dienoic acid $\mathrm{IC}_{50}$, median inhibitory concentration.

* Corresponding author. world (Carmichael et al., 1985; Andersen et al., 1993; Hallegraeff, 1993), and cyanobacteria contamination of water supplies may lead to potential hazards to human health (Falconer et al., 1983; Gorham and Carmichael, 1988). Microcystins are composed of a heptapeptide ring containing the unusual residue $N$-methyldehydroalanine and three $\beta$-amino acids with little molecular variation, and two L-amino acids that show considerable variation (Carmichael et al., 1988). MicrocystinLR, for example, contains the two L-amino acids leucine and arginine in these variant positions 
(Fig. 1). The seventh residue is a unique hydrophobic $\beta$-amino acid (Rinehart et al., 1988), normally referred to as Adda (3-amino-9methoxy-2,6,8-trimethyl-10-phenyldeca-4,6-dienoic aci) (Rinehart et al., 1988). Microcystins and related polypeptides are selectively hepatotoxic in fish, birds and mammals (Falconer et al., 1981; Carmichael et al., 1985). The consequence of acute poisoning by these compounds is rapid disorganisation of the hepatic architecture, breakdown of sinusoidal structures and, in mammals, pooling of blood in the liver (Falconer et al., 1981; Eriksson et al., 1990). Chronic uptake of microcystins results in generalised hepatocyte degeneration with necrosis, progressive fibrosis and mononuclear leukocyte infiltration (Elleman et al., 1978). Additionally, it was shown that microcystin-LR acts as a potent tumor promoter (Nishiwaki-Matsushima et al., 1992). At the biochemical level, toxicity of microcystin and related polypeptides involves the specific inhibition of several protein phosphatases (Honkanen et al., 1990; MacKintosh et al., 1990; Yoshizawa et al., 1990). These enzymes are of primary importance in regulating cellular morphology and functions by virtue of their capacity to remove phosphate groups from protein substrates (Cohen, 1989).

Several studies involving intraperitoneal or intravenous injection of radiolabelled microcystins to rats and mice demonstrated that these polypeptides are selectively targeted to the liver, while only marginal amounts of radioactivity were found in other organs, such as the kidneys, or in the blood (Falconer et al., 1986; Runnegar et al., 1986; Brooks and Codd, 1987; Robinson et al., 1991). Competition experiments indicated that microcystins are carried into hepatocytes by the multispecific organic anion transporters which move bile acids into hepatocytes, thus explaining their organotropy (Hooser et al., 1991; Runnegar et al., 1991).

On the other hand, only little information is available on possible elimination pathways of cyanobacteria polypeptides after their uptake into parenchymal liver cells. In one study performed on female rats, small-intestinal contents and urine contained 9 and $3 \%$ of total radioactivity, respectively, $2 \mathrm{~h}$ after intravenous injection of $\left[{ }^{125} \mathrm{I}\right]-$ radiolabelled microcystin-YM (Falconer et al., 1986). Similarly, Robinson et al. (1991) reported that $15 \%$ of radioactivity was recovered in feces and $9 \%$ in urine within 6 days after intravenous injection of $\left[{ }^{3} \mathrm{H}\right]$-labelled microcystin-LR in mice. These reports suggested biliary excretion of microcystins, but the presence of these hepatotoxins in the bile of poisoned animals has not been tested directly.

In the present study, we have exploited the specific inhibition of protein phosphatase activily to detect microcystins in the bile of fish that were orally exposed to hepatotoxic Microcystis aeruginosa. Our results indicate that these compounds may be excreted from hepatocytes into the bile as biochemically active molecules.

\section{Materials and methods}

\subsection{Rainbow trout}

Experiments were carried out on one-year-old rainbow trout (Oncorhynchus mykiss), mean weight 30-60 g (Thedy Waser Commercial Fish Hatchery, Andelfingen, Switzerland). Thirty fish were acclimated 2 weeks in flowthrough aquaria containing $15-18^{\circ} \mathrm{C}$ dechlorinated tap water and then transferred to $100-1$ aerated recirculation tanks for the experiments. Ad libitum feeding with commercial food was interrupted $24 \mathrm{~h}$ before exposure to cyanobacteria. Prior to treatment, trout were anaesthetised in a $100 \mathrm{mg} / \mathrm{l}$ solution of Tricaine (Fluka, Buchs, Switzerland).

\subsection{Experimental protocol}

Crude algae biomass obtained from Microcystis aeruginosa PCC 7806 was freeze-dried and suspended in dechlorinated water. Fish were orally gavaged with a dose of $1.22 \mathrm{~g}$ biomass $/ \mathrm{kg}$ body weight in a volume of $1 \mathrm{ml}$ as described (Tencalla et al., 1994). HPLC analysis of this Microcystis aeruginosa biomass yielded an average hepatotoxin content of $4.6 \mathrm{mg}$ microcystin-LR/g dry weight (Tencalla et al., 1994). Groups of three animals were scarified $1,3,12,24,48$ and $72 \mathrm{~h}$ after treatment. Bile was collected from gallbladders and stored at $-20^{\circ} \mathrm{C}$. Control fish were gavaged with 1 $\mathrm{ml}$ of plain dechlorinated water. 


\subsection{Extraction of microcystins from bile}

Gallbladder contents $(5-150 \mu 1)$ were freezedried, resuspended in $500 \mu \mathrm{l}$ methanol, and extractcd for $18 \mathrm{~h}$ at $4^{\circ} \mathrm{C}$. The methanol was decanted, fresh methanol $(500 \mu 1)$ was added and, after incubation in a sonicating water bath for 5 min at room temperature, extraction was repeated for $1 \mathrm{~h}$ at $4^{\circ} \mathrm{C}$. The two methanol extracts were combined and dried in a SpeedVac concentrator (Savant Instruments Inc., Farmingdale, NY, USA). The dried material was resuspended in 50 $\mathrm{mM}$ Tris- $\mathrm{HCl}, \mathrm{pH} 7.0,0.1 \mathrm{mM}$ EGTA, and $0.1 \%$ (v/v) 2-mercaptoethanol, to reconstitute the original sample volume, and stored in small aliquots at $-80^{\circ} \mathrm{C}$.

\subsection{Preparation of rapeseed extracts}

Cytosolic extracts from Brassica napus seeds were prepared as outlined by MacKintosh and Cohen (1989) with the following modifications. Seeds were collected 70 days after flowering and stored at $-80^{\circ} \mathrm{C}$. Seeds were homogenised for $30 \mathrm{~s}$ $(2 \times 15 \mathrm{~s})$ in $50 \mathrm{mM}$ Tris- $\mathrm{HCl}, \mathrm{pH} 7.0,4 \mathrm{mM}$ EDTA, $250 \mathrm{mM}$ sucrose, $1 \mathrm{mM}$ phenylmethanesulphonyl fluoride, $1 \mathrm{mM}$ benzamidine, and $0.2 \%$ (v/v) 2-mercaptoethanol using a household blender. The homogenate was further processed as described (MacKintosh and Cohen, 1989), to obtain a cytosolic extract that was stored in small aliquots at $-80^{\circ} \mathrm{C}$. Protein concentration in the rapeseed extract was $18.1 \mathrm{mg} / \mathrm{ml}$, as determined by the Bradford (1976) method.

\subsection{Protein phosphatase assay}

The preparation of radiolabelled phosphorylase $a$ was as described by Cohen et al. (1988), but ${ }^{32} \mathrm{P}$ was replaced with ${ }^{33} \mathrm{P}$. Phosphatase reactions contained $50 \mathrm{mM}$ Tris- $\mathrm{HCl}$, pH 7.0,0.01\%(w/v) Brij35, 0.1 mM EGTA, 0.1\% 2-mercaptoethanol, 100 $\mu \mathrm{g}$ bovine serum albumin, $9 \mu \mathrm{g}$ of rapeseed extract, and $1 \mu \mathrm{g}{ }^{33} \mathrm{P}$-phosphorylase $a$ in a final volume of $30 \mu \mathrm{l}$. One $\mu \mathrm{l}$ of the methanol-extracted bile sample to be tested was added either directly to this reaction mixture, to obtain a final dilution of $1: 30$, or after diluting with $50 \mathrm{mM}$ Tris- $\mathrm{HCl}, \mathrm{pH} 7.0,0.1$ mM EGTA, $0.1 \%(\mathrm{v} / \mathrm{v})$ 2-mercaptoethanol, to obtain final dilutions of 1:300, 1:3000, and 1:30000, as indicated in Fig. 2. After incubation at $30^{\circ} \mathrm{C}$ for
$30 \mathrm{~min}$, phosphatase activity was stopped by the addition of $0.15 \mathrm{ml}$ ice-cold $20 \%$ (w/v) trichloroacetic acid. The suspension was allowed to stand on ice for $5 \mathrm{~min}$, and then centrifuged for $5 \mathrm{~min}$ at $13500 \times g$ and $4^{\circ} \mathrm{C}$. A fraction of the supernatant $(0.1 \mathrm{ml})$ was removed, mixed with $5 \mathrm{ml}$ scintillation cocktail, and quantified in a Beckman LS600 counter. All values were corrected for background radioactivity obtained in the supernatant when control samples were incubated in the absence of rapeseed extract. Phosphatase activities were expressed as the percentage of ${ }^{33} \mathrm{P}$ released in control reactions incubated in the absence of any protein phosphatase inhibitory material.

\subsection{Data analysis}

A sample dilution factor, at which enzyme activity was reduced by $50 \%$, was determined by linear interpolation of the phosphatase inhibition data. Using a pure microcystin-LR standard (Sigma Chemical Company, St. Louis, MO, USA), we found $50 \%$ inhibition of phosphatase activity at a toxin concentration of $0.25 \mathrm{ng} / \mathrm{ml}$ in the reaction mixture. The concentration of cyanobacteria hepatotoxins in a particular bile sample was then calculated by multiplying this median concentration for inhibition $(0.25 \mathrm{ng} / \mathrm{ml})$ by the dilution factor obtained in the phosphatase inhibition assay. The resulting concentrations were expressed as microcystin-LR equivalents.

\section{Results}

\subsection{Phosphatase inhibition assay}

To detect the presence of cyanobacteria toxins in biological samples we exploited the ability of these compounds to selectively inhibit protein phosphatases. The phosphatase inhibition assay is outlined in Fig. 1. Soluble extracts prepared from Brassica napus seeds contain high levels of phosphatase enzymes which cleave the covalent bond between protein substrates and their phosphate groups, thereby generating dephosphorylated proteins and inorganic phosphate (Cohen et al., 1988; Cohen, 1989). In this study, we used ${ }^{33} \mathrm{P}$-phosphorylase $a$ as a protein substrate, and measured the amount of ${ }^{33} \mathrm{P}$ released during incubations with extracts from Brassica napus (Fig. 1). Pre- 

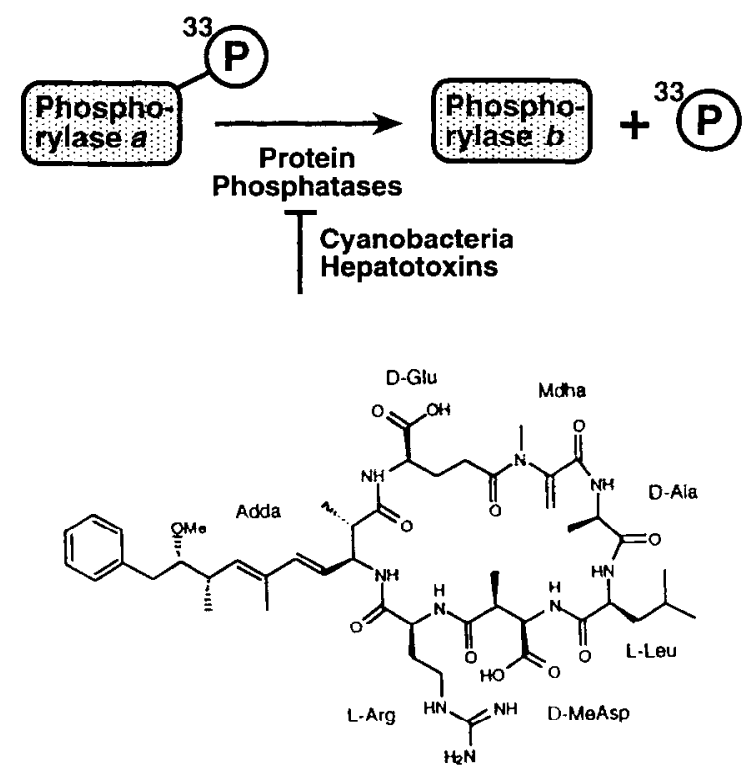

Fig. 1. Structure of microcystin-LR and schematic diagram illustrating the biochemical reaction used to detect its presence in biological samples. Protein phosphatases catalyse the enzymatic cleavage of phosphate groups from ${ }^{33} \mathrm{P}$-phosphorylase a to produce phosphorylase $b$. This reaction is specifically inhibited by microcystin and related polypeptides produced by hepatotoxic cyanobacteria. Microcystin-LR is a cyclic heptapeptide consisting of the three invariant $D$-amino acids alanine (D-Ala), erythro- $\beta$-methylaspartic acid (D-MeAsp), and glutamine (D-Glu), the two unusual amino acids $N$-methyldehydroalanine (Mdha) and 3-amino-9-methoxy-2,6,8-trimethyl-10-phenyldeca-4,6-dienoic acid (Adda), and the two variant L-amino acids leucine (L-Leu) and arginine (L-Arg). The molecular mass of microcystin-LR is $994 \mathrm{Da}$.

vious reports demonstrated that this phosphatase reaction is potently inhibited by microcystin-LR, with median concentrations for inhibition $\left(\mathrm{IC}_{50}\right)$ in the range of $0.04-8 \mathrm{nM}$, depending on the assay conditions (Runnegar et al., 1993). Inhibition of phosphatase activity was shown to depend not only on microcystin concentration but also on the concentration of the phosphatases present in the reaction (Honkanen et al., 1990). Under the conditions used in our study, $50 \%$ inhibition of phosphatase activity was observed at microcystin-LR concentrations in the assay mixture of $0.25 \mathrm{nM}$, corresponding to $0.25 \mathrm{ng} / \mathrm{ml}$.

\subsection{Recovery of bile samples from experimentally poisoned fish}

Animals were orally dosed with $1.22 \mathrm{~g}$ Microcystis aeruginosa algae biomass $/ \mathrm{kg}$ body weight, corresponding to $5.6 \mathrm{mg}$ microcystin- $\mathrm{LR} / \mathrm{kg}$ body weight (Tencalla et al., 1994). This dose produced first signs of poisoning 12-24 h after treatment, and led to a toxic response within $96 \mathrm{~h}$ after treatment. The same algae biomass was shown to be acutely toxic via intraperitoneal injection at a dose approximately 10 -times lower, indicating that oral bioavailability of the toxin is approximately $10 \%$ (Tencalla et al., 1994). To collect bile samples, groups of three fish were sacrificed 1, 3, 12, 24, 48 and $72 \mathrm{~h}$ after oral administration of the toxic biomass. Bile recovery was variable and, in some cases, we were unable to obtain any material either because gallbladders ruptured during the manipulations or because they were completely empty. Bile from all three animals was collected in the 24-, 48- and 72-h groups, but only two samples were obtained from the 1-h group and only one sample from the 3- and 12-h groups. In summary, bile could be recovered from 13 of 18 treated fish. The mean yield of bile from poisoned and control animals was $52 \pm 45 \mu \mathrm{l}(n=13)$ and $91 \pm 51 \mu 1$ $(n=10)$, respectively.

\subsection{Enzymatic detection of cyanobacteria toxins in bile samples}

Bile samples were processed by methanol extraction and tested by phosphatase inhibition assays. To allow direct comparisons between individual samples, methanol-extracted and dried samples were reconstituted with appropriate amounts of buffer to obtain exactly the same volume as the original bile samples (see Materials and methods for details). For each time point, a control sample collected from mock-treated fish was also included in the analysis. In all cases examined, we found that samples from poisoned fish reduced phosphatase activity to a greater extent than control samples (Fig. 2), indicating specific inhibition by hepatotoxic cyanobacteria components. The most potent inhibition of protein phosphatase activity was observed with the bile sample collected $3 \mathrm{~h}$ after cyanobacteria treatment. In fact, this sample completely suppressed phosphatase activity even 
$1 \mathrm{~h}$
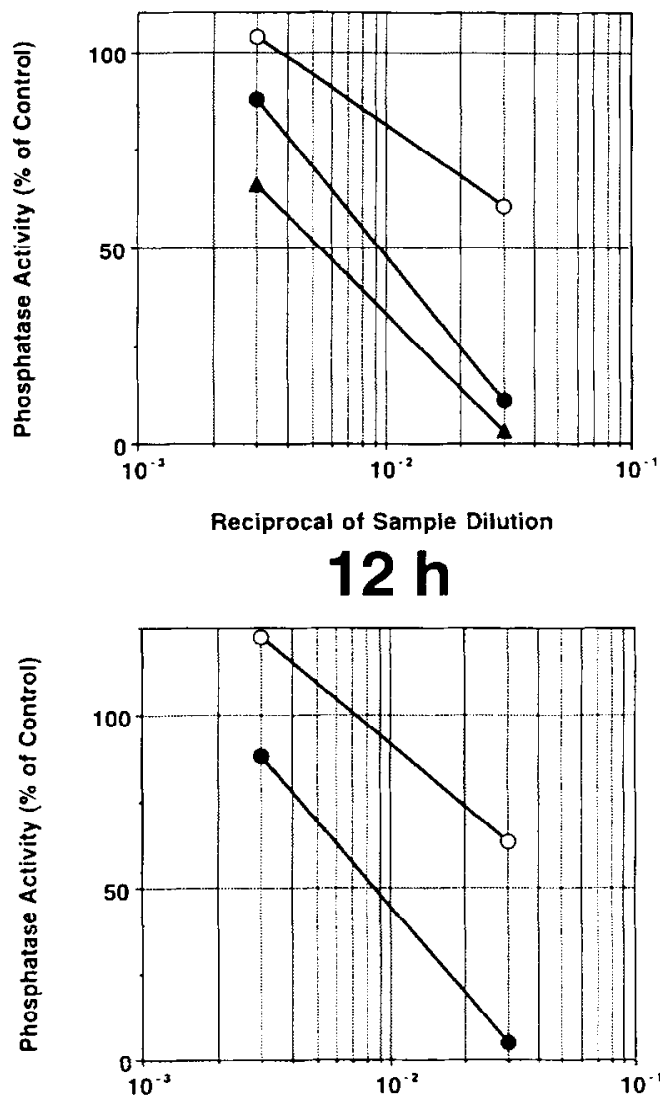

Reciprocal of Sample Dilution

$48 \mathrm{~h}$

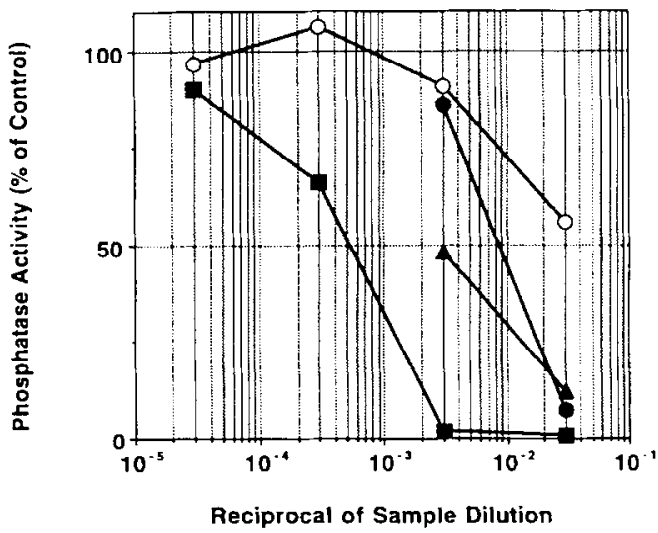

$3 \mathrm{~h}$

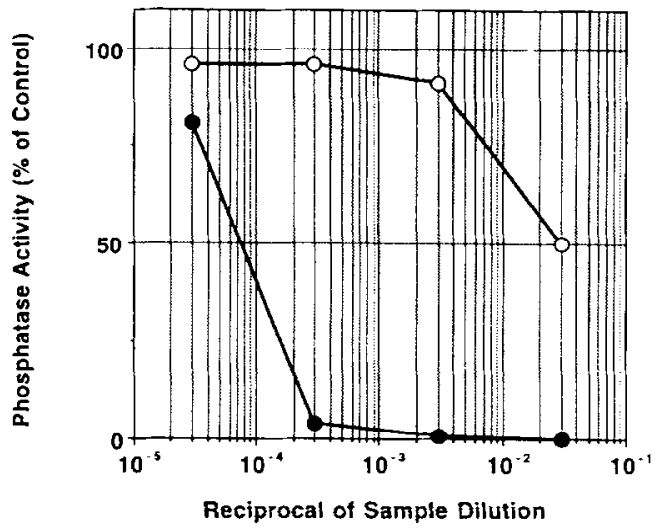

$24 \mathrm{~h}$

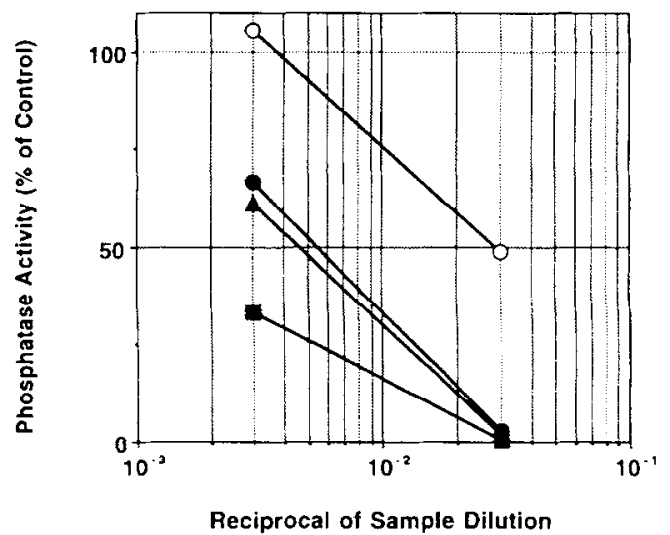

$72 \mathrm{~h}$

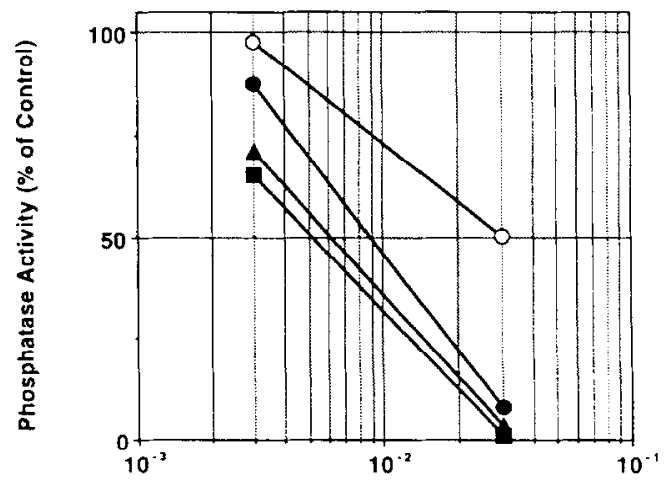

Reciprocal of Sample Dilution

Fig. 2. Detection of cyanobacteria hepatotoxins in bile samples. Gallbladder contents from control (O) or cyanobacteria-treated fish $(\boldsymbol{O}, \boldsymbol{\Lambda}, \mathbf{D})$ were processed by methanol extraction and tested at various dilutions in the phosphatase inhibition assay. Bile samples were obtained 1, 3, 12, 24, 48 and $72 \mathrm{~h}$ after oral administration of toxic cyanobacteria. Phosphatase activities are expressed as the percentages of enzyme activity obtained in control reactions incubated in the absence of bile samples, and are plotted as a function of the reciprocal of the sample dilution. Each value represents the average of two to three independent determinations. In the presence of bile samples diluted at 1:30, the mean values of phosphatase activity were $60.4 \pm 11.7 \%$ of control with untreated fish ( $n=6$ ), but only $3.8 \pm 3.9 \%$ with cyanobacteria-treated fish $(n=13)$. Upon analysis by Student's $t$-test this difference was found to be highly significant $(P<0.005)$. 
when diluted more than 1000-fold (Fig. $2 ; 3$ h). In comparison, the corresponding control material displayed only marginal effects on phosphatase activity at 100 -fold or higher dilutions (Fig. $2 ; 3 \mathrm{~h}$ ). By linear interpolation of the phosphatase inhibition data, we determined that $50 \%$ inhibition of enzyme activity is expected at a 14000 -fold dilution of the 3-h sample from poisoned fish (Fig. 2; $3 \mathrm{~h}$ ). Considering that under identical reaction conditions pure microcystin-LR produced $50 \%$ inhibition of phosphatase activity at a concentration of $0.25 \mathrm{ng} / \mathrm{ml}$, this dilution factor of 14000 translates to an apparent hepatotoxin concentration of $3.5 \mu \mathrm{g} / \mathrm{ml}$ of bile, expressed as microcystinLR equivalents.

Relatively high concentrations of cyanobacteria hepatotoxins were also observed in bile samples obtained 24 and $48 \mathrm{~h}$ after exposure (Fig. 2; 24 and $48 \mathrm{~h}$ ). At these time points, bile could be recovered from all three animals in both experimental groups, and $50 \%$ inhibition of phosphatase activity was found at dilutions ranging from $\sim 190$ - to $\sim 1000$-fold in the 24-h group (Fig. $2 ; 24 \mathrm{~h}$ ), and ranging from $\sim 140$ - to $\sim 1900$-fold in the $48-\mathrm{h}$ group (Fig. 2; 48h). In contrast, control samples derived from mock-treated fish resulted in little or no inhibition of phosphatase activity at most of these dilutions. The dilution factors determined in these two experimental groups translate to a broad spectrum of hepatotoxin concentrations, ranging from 35 to $475 \mathrm{ng} / \mathrm{ml}$ of bile, expressed as microcystin-LR equivalents. The calculated mean values are 118 and $203 \mathrm{ng} / \mathrm{ml}$ after 24 and $48 \mathrm{~h}$, respectively.

Bile samples collected 1,12 and $72 \mathrm{~h}$ after cyanobacteria administration also contained detectable amounts of cyanobacteria toxins. When tested at dilutions of 1:30, these samples inhibited phosphatase activity more potently than the corresponding controls, although substantial inhibition of enzyme activity was observed only at dilutions that also resulted in some nonspecific suppression of phosphatase activity (Fig. 2; 1, 12 and $72 \mathrm{~h}$ ). However, the results of Fig. 2 show that hepatotoxins became detectable in bile samples as early as $1 \mathrm{~h}$ after oral administration of cyanobacteria, and remained detectable for up to 3 days after this exposure.

\section{Discussion}

Irreversible inhibition of phosphatase activity is thought to represent the biochemical basis of microcystin toxicity (Honkanen et al., 1990; MacKintosh et al., 1990; Yoshizawa et al., 1990). In the present study, we have used this enzymatic inhibition to detect the presence of microcystin in the bile of fish that were experimentally poisoned by oral administration of hepatotoxic cyanobacteria. In all cases examined, bile samples obtained from poisoned animals produced stronger inhibition of in vitro phosphatase activity than the corresponding samples derived from mock-treated controls. This specific inhibition of phosphatase activity indicates that cyanobacteria hepatotoxins were excreted into the bile of poisoned fish.

By comparison with a pure microcystin-LR standard, we were able to estimate the hepatotoxin concentrations in the tested samples. For that purpose, we first determined the sample dilution factors necessary to obtain $50 \%$ inhibition of phosphatase activity, and then used this factor to calculate hepatotoxin concentration in the samples, which were expressed as microcystin-LR equivalents. These calculations were based on the finding that pure microcystin-LR displayed an $\mathrm{IC}_{50}$ of $\sim 0.25 \mathrm{ng} / \mathrm{ml}$ under the assay conditions used in this study. The highest concentrations of phosphatase inhibitory material were found in the bile samples collected 3 and $48 \mathrm{~h}$ after oral administration of the toxic biomass. In particular, the sample collected $3 \mathrm{~h}$ after treatment, with a hepatotoxin concentration of $3.5 \mathrm{mg} / \mathrm{ml}$, and one sample collected $48 \mathrm{~h}$ after treatment, with a hepatotoxin concentration of $475 \mathrm{ng} / \mathrm{ml}$, suggest that a considerable fraction of these compounds are excreted from hepatocytes into the biliary tract. We did not observe any significant effects of cyanobacteria hepatotoxins on the total amount of bile stored in the gallbladders. For example, the 3h sample contained the highest toxin concentration, but its volume $(\sim 100 \mu \mathrm{l})$ was within the normal range obtained from control animals.

Methanol was used for bile extraction because it was previously found to be the most versatile solvent for the simultaneous extraction of different microcystin variants from biological samples 
(Lawton et al., 1994). Several studies show, on the other hand, that microcystins and related cyclic polypeptides form highly stable, apparently covalent bonds with their intracellular targets (Falconer et al., 1986; Brooks and Codd, 1987; Robinson et al., 1991). As a consequence, extraction by methanol or other solvents is likely to yield only those hepatotoxin molecules which are not covalently bound to proteins. Interestingly, the biliary hepatotoxin concentrations found in this study are severalfold higher than those detected in methanol extracts of crude homogenates obtained from the corresponding liver samples (F.G. Tencalla and D.R. Dietrich, manuscript in preparation). This difference between liver tissue and bile indicates transport of unbound hepatotoxins against a concentration gradient.

The mechanisms by which bile acids and other organic anions are excreted into the bile are not perfectly understood. $\Lambda$ carrier protein has been identified that utilises the membrane potential to transport bile acids into the canalicular lumen (Meyer et al., 1987). However, the transmembrane potential difference of $-35 \mathrm{mV}$ could not account for the large concentration gradients of bile acids (Gatmaitan et al., 1994). This consideration led to the discovery of an ATP-dependent bile acid transport system that is able to generate steep concentration gradients (Nishida et al., 1991). Alternatively, cyanobacteria hepatotoxins may be transported to the bile by a canalicular carrier that is distinct from that of bile acids. Of particular interest is an energy-dependent transporter which carries a broad range of organic anions across the bile canaliculus (Kitamura et al., 1990), but it is likely that other potential transport systems may be discovered in the future (Gatmaitan et al., 1994).

To our knowledge, this is the first study showing that cyanobacteria hepatotoxins excreted from the liver retain their potent biochemical activity, i.e., inhibtion of protein phosphatase activity. At this time, it is not known whether the inhibitory material identified in bile samples reflects unmodified microcystin. In one study (Robinson et al., 1991), most radiolabel found in feces after intravenous injection of $\left[{ }^{3} \mathrm{H}\right]$ microcystin-LR into mice was identified as parent toxin upon HPLC analysis.
This finding suggests that microcystin-LR may be directly secreted into the bile without preceding biotransformation reactions. In any case, our study indicates that microcystin is accumulated in the biliary tract of poisoned fish in a biochemically active form.

\section{Acknowledgements}

This study was supported by grant 012.91.11 from The Bundesamt für Veterinärwesen (Naegeli) and grant 31-33344.92 from the Swiss National Science Foundation (Dietrich). A. Sahin is a research assistant at the Department of Internal Diseases and Pharmacology, University of Yüzüncü Yil, Van, Turkey.

\section{References}

Andersen, R.J., Lou, H.A., Chen, D.Z.X., Holmes, C.F.B., Kent, M.L., Le Blanc, M., Taylor, F.J.R. and Williams, D.E. (1993) Chemical and biological evidence links microcystins to salmon 'netpen liver disease'. Toxicon 31, 1315-1323.

Bradford, M.M. (1976) A rapid and sensitive method for the quantitation of microgram quantities of protein utilizing the principle of protein-dye binding. Anal. Biochem. 72, 248-254.

Brooks, W.P. and Codd, G.A. (1987) Distribution of Microcystis aeruginosa peptide toxin and interactions with hepatic microsomes in mice. Pharmacol. Toxicol. 60, 187-191.

Carmichael, W.W., Jones, C.L.A., Mahmood, N.A. and Theiss, W.C. (1985) Algal toxins and water-based diseases. CRC Crit. Rev. Environ. Control 15, 275-313.

Carmichael, W.W., Beasley, V.R., Bunner, D., Eloff, J., Falconer, I., Gorham, P., Harada, K-I., Yu, M-J., Krishmamurthy, T., Moore, R.E., Rinehart, K.L., Runnegar, M.T., Skullberg, O.M. and Watanabe, M. (1988) Naming of cyclic heptapeptide toxins of cyanobacteria (bluegreen algae). Toxicon 26, 921-923.

Cohen P. (1989) The structure and regulation of protein phosphatases. Annu. Rev. Biochem. 58, 453-508.

Cohen, P., Alemany, S., Heminings, B.A., Resink, T.J., Stralfors, P. and Tung, H.Y.L. (1988) Protein phosphatase-1 and protein phosphatase-2A from rabbit skeletal muscle. Methods Enzymol. 159, 390-408.

Elleman, T.C., Falconer, I.R., Jackson, A.R.B. and Runnegar, M.T. (1978) Isolation, characterization and pathology of the toxin from a Microcystis aeruginosa (=Anacystis cyanea) bloom. Aust. J. Biol. Sci. 31, 209-218.

Eriksson, J.E., Toivola, D., Meriluoto, J.A.O., Karaki, H., Han, Y-G. and Hartshorne, D. (1990) Hepatocyte deformation induced by cyanobacterial toxins reflects inhibition of protein phosphatases. Biochem. Biophys. Res. Commun. 173, 1347-1353. 
Falconer, I.R., Jackson, A.R.B., Langley, J. and Runnegar, M.I.C. (1981) Liver pathology in mice in poisoning by the blue-green alga Microcystis aeruginosa. Aust. J. Biol. Sci. 34 , 179-187.

Falconer, I.R., Beresford, A.M. and Runnegar, M.T.C. (1983) Evidence of liver damage by toxin from a bloom of the bluegreen alga Microcystis aeruginosa. Med. J. Aust. 1, 511-514.

Falconer, I.R., Buckley, T. and Runnegar, M.T.C. (1986) Biological half-life, organ distribution and excretion of ${ }^{125} \mathrm{I}-$ labeled toxic peptide from the blue-green alga Microcystis aeruginosa. Aust. J. Biol. Sci. 39, 17-21

Gatmaitan, Z., Leveille-Webster, C.R. and Arias, I.M. (1994) The biology of the bile canaliculus. In: I.M. Arias, J.L Boyer, N. Fausto, W.B. Jakoby, D. Schachter and D.A Schafritz (Eds), The Liver. Biology and Pathobiology. Raven Press, New York, pp. 665-675.

Gorham, P.R. and Carmichael, W.W. (1988) Hazards of freshwater blue-green algae (cyanobacteria). In: A.A. Lembi and J.R. Waaland (Eds), Algae and Human Affairs. Cambridge University Press, Cambridge, pp. 403-431.

Hallegraeff, G.M. (1993) A review of harmful algal blooms and their apparent global increase. Phycologia 32, 79-99.

Honkanen, R.E., Zwiller, J., Moore, R.E., Daily, S.L., Khatra, B.S., Dukelow, M. and Boynton, A.L. (1990) Characterization of microcystin-LR, a potent inhibitor of type-I and type2A protein phosphatases. J. Biol. Chem. 265, 19401-19404.

Hooser, S.B., Kuhlenschmidt, M.S., Dahlem, A.M., Beasley, V.R., Carmichael, W.W. and Haschek, W.M. (1991) Uptake and subcellular localization of tritiated dihydro-microcystin LR in rat liver. Toxicon. 29, 589-601.

Kitamura, T., Jansen, P., Hardenbrook, C., Kamimoto, U., Gatmaitan, Z. and Arias, I.M. (1990) Defective ATPdependent bile canalicular transport of organic anions in mutant (TR-) rats with conjugated hyperbilirubinemia. Proc. Natl. Acad. Sci. IJSA 87, 3557-3561

Lawton, L.A., Edwards, C. and Codd, A. (1994) Extraction and high-performance liquid chromatographic method for the determination of microcystins in raw and treated waters. Analyst. 119, 1525-1530.

Mackintosh, C. and Cohen, P. (1989) Identification of high levels of type I and type $2 \mathrm{~A}$ protein phosphatases in higher plants. Biochem. J. 262, 335-339.

MacKintosh, C., Beattie, K.A., Klumpp, S., Cohen, P. and
Codd, G.A. (1990) Cyanobacterial microcystin-LR is a potent and specific inhibitor of protein phosphatases 1 and $2 A$ from both mammals and higher plants. FEBS Lett. 264. 187-192.

Meyer, P.J., Meier-Abt, A.S. and Boyer, 1.L. (1987) Properties of the canalicular bile acid transport system in rat liver. Biochem. J. 242, 465-469.

Nishida, T., Gatmaitan, Z., Che, M. and Arias, 1.M. (1991) ATP-dependent canalicular bile acid transport: another piece of the puzzle. Proc. Natl. Acad. Sci. USA 88, 6590-6594.

Nishiwaki-Matsushima, R., Ohta, T., Nishiwaki, S., Suganuma, M., Kohyama, K., Ishikava, T.. Carmichael, W.W. and Fujiki, H. (1992) Liver tumor promotion by the cyanobacterial cyclic peptide toxin microcystin-LR. J. Cancer Res. Clin. Oncol. 118, 420-424.

Rinehart, K.L., Harada, K., Namikoshi, M., Chen, C., Harvis, C.A., Munro, M.H.G., Blunt, J.W., Mulligan, P.E., Beasley, V.R., Dahlem, A.M. and Carmichael, W.W. (1988) Nodularin, microcystin, and the configuration of Adda. J. Am. Chem. Soc. 110, 8557-8558.

Robinson, N.A., Pace, J.G., Matson, C.F., Miura, G.A. and Lawrence, W.B. (1991) Tissue distribution, excretion and hepatic biotransformation of microcystin-LR in mice. $J$. Pharmacol. Exp. Ther. 256, 176-182.

Runnegar, M.T.C., Falconer I.R., Buckley, T. and Jackson, A.R.B. (1986) Lethal potency and tissue distribution of ${ }^{125} \mathrm{I}$ labelled toxic peptides from the blue-green alga Microcystis aeruginosa. Toxicon 24, 506-509.

Runnegar, M.T.C., Gerdes, R.G. and Falconer, I.R. (1991) The uptake of the cyanobacterial hepatotoxin microcystin by isolated rat hepatocytes. Toxicon 29, 43-51.

Runnegar, M.T.C., Kong, S. and Berndt, N. (1993) Protein phosphatase inhibition and in vivo hepatotoxicity of microcystins. Am. J. Phys. 265, G224-G230.

Tencalla, F., Dietrich, D. and Schlatter, C. (1994) Toxicity of Microcystis aeruginosa peptide toxin to yearling rainbow trout (Onchrhyncus mykiss). Aquat. Toxicol. 30, 215-224.

Yoshizawa, S., Matsushima, R., Watanabe, M.F., Ilarada, K., Ichihara, A., Carmichael, W.W. and Fujiki, H. (1990) Inhibition of protein phosphatases by microcystis and nodularin associated with hepatotoxicity. J. Cancer Res. Clin. Oncol. 116, 609-614. 